\title{
The Scope of an Alternative Medicine to Cure Oral Diseases
}

\section{Neeraja Turagam* and Durga Prasad Mudrakola}

Department of Prosthodontics, AIMST University Kedah, Malaysia

*Corresponding author: Dr. Neeraja Turagam, MDS, Department of Prosthodontics, AIMST University Kedah, Malaysia, Tel: +60108153173; Fax: +278615107002; Email: neer222@gmail.com

Received date: July 03, 2017; Accepted date: September 08, 2017; Published date: September 15, 2017

Copyright: @ 2017 Turagam N. This is an open-access article distributed under the terms of the Creative Commons Attribution License, which permits unrestricted use, distribution, and reproduction in any medium, provided the original author and source are credited.

\begin{abstract}
Objective: Inducing positive results without sacrificing the integrity of their own well-being and also the well-being of our planet is the way of life. Oral diseases are one in all the foremost necessary issues, public health demands are on the increase in developing countries. Most of the oral diseases are caused due to the microorganism infections. The anti-bacterial activity of medicative plants are attributable to the presence of potential bioactive compounds, that facilitate to scale back microorganisms load within the oral cavity/mouth and so stop the formation of plaque, caries and ulcers.
\end{abstract}

Background: Ayurveda is one such ancient Indian system of health-care and longevity. Ayurvedic treatment is aimed toward a patient as associate organic whole and treatment consists of salubrious use of medication, diets and sure practices.

Method: Data were performed in PubMed Central and Cochrane library using MeSH Terms - Dentistry, Herbal Medicine, Periodontitis, AYUSH analysis Portal, National Library of writing medication, Systematic Reviews in writing, writing information, net of Science, Indus Medicus and Google Scholar; by consulting existing bibliographies; by exploitation each forward and backward reference chaining techniques; and by pursuit recent activities within the field of writing, that is primarily involved with bar and management of orofacial disorders.

Conclusion: The present scientific proof based review is targeted on the potential role of writing within the management of assorted orofacial disorders. The aim of this review is to bring the attention of natural Ayurvedic medicine before it fades away.

Keywords Ayurveda; Dentistry; Oral health; Phyto-chemicals; Orofacial disorders

\section{Introduction}

A holistic system of medication that evolved in Asian country some 3000-5000 years ago, a system of ancient medication native to the Indian landmass, currently practiced in different components of the planet as a sort of medicine [1]. The Suśruta Samhitā and also the Charaka Samhitā area unit its earliest authoritative texts [2]. Over the centuries, Ayurvedic practitioners developed massive numbers of medicative preparations and surgical procedures for the treatment of varied ailments and diseases [3]. Albeit dental medicine wasn't a specialised branch of piece of writing, it's enclosed in its Shalakya Tantra (system of surgery).

Oral diseases still are a serious ill health world-wide [4]. Tooth decay and dental medicine diseases area unit the foremost usually seen international oral health issues [5]. The link between oral diseases and also the activities of microorganism species that type a part of the small accumulation of the oral cavity is well-established [6-8]. Despite many chemical agents being commercially accessible, these will alter oral small accumulation and have undesirable side-effects like regurgitation, diarrhoea and tooth staining $[9,10]$, moreover, the quality Western medication has had solely restricted success within the bar of periodontitis and within the treatment of a range of oral diseases. Hence, the seek for various product continues and natural phytochemicals isolated from plants employed in ancient medication area unit thought of pretty much as good alternatives to artificial chemicals [11].

Ayurveda had mentioned various procedures for maintaining oral hygiene. These include procedures like gandusha, kavala, dantadhavana, and jivha lekhana (cleaning tongue) [12]. The botanicals within the Ayurvedic material medica are tried to be safe and effective, through many hundred to many thousand years of use [13]. The exploration of botanicals employed in ancient medication, could cause the event of novel preventive or therapeutic ways for oral health [14]. As most of the oral diseases area unit thanks to microorganism infections and it's been well-documented that medicative plants confer sizable anti-bacterial activity against varied microorganisms together with bacteria's accountable for tooth decay $[15,16]$

The medical practitioner has to be additional informed relating to the utilization, safety and effectiveness of the assorted ancient medicines and over-the-counter product. As this is often hardly explored half for the sector of dental medicine, there's a requirement for integration of skilled dental treatment modalities and complementary various medical (CAM) systems to produce the most effective and distinctive from every system to patients as a complementary medical aid and another selection of treatment $[17,18]$. Considering the importance of varied ancient or CAM systems, this scientific proof based mostly review of literature is 
targeted on the attainable role of piece of writing within the management of varied orofacial disorders.

\section{Ayurveda and Oral Health}

The body constitution is classed supported the predominance of 1 or a lot of of the 3 doshas, vata, tyrannid and kapha. The dominance dosha has been disclosed in each the individual and nature determines health care in piece of writing, together with dental health [19]. A balance among the 3 doshas is important for health that governs all metabolic activities. Once their actions in our mind-body constitution area unit balanced, we tend to expertise psychological and physical eudaemonia [20].

All of these oro facial diseases are often treated with material that advocates procedures like oral cleansing, extractions, excisions, flap surgeries etc., written material conjointly recommends daily use of assorted therapeutic procedures for the hindrance and maintenance of oral health. These include: Dant Dhavani (Brushing), JivhaLekhana (Tongue scrapping) Gandoosha or Oil propulsion/Oil Pulling (Gargling) Dant Dhavani (Brushing). Ayurveda recommends chew sticks within the morning yet as when each meal to forestall diseases. Ayurveda insists on the utilization of flavoring brushes, just about 9 inches long and also the thickness of one's little finger [21-23]. These herb sticks ought to be either "kashaya" (astringent), "katu" (acrid) or "tikta" (bitter) in style. The tactic of use is to crush one finish, chew it and eat it slowly. The arishth|tree\} (margosa or Azadirachta indica) could be a known flavoring chew stick. Mentioned that contemporary stems of liquorice (Glycyrrhiza glabra), infusion or the tannin tree (Acacia Catechu Linn.), Arjuna tree (Termmalia arjuna), fever nut (Caesalipinia bouduc) and milkweed plant (Calotropis procera) may be used for brushing. Chew on these stems is believed to cause attrition and leveling of biting surfaces, facilitate secretion secretion and probably, facilitate in plaque management whereas some stems have associate anti-bacterial action [24]. Various Ayurvedic herbs and natural products have been used for their pharmacological applications viz. antiulcer, wound healing, anti-inflammatory, antimicrobial and antioxidant properties and have been proven to be safe and effective for oral disease and hygiene including various therapeutic Ayurvedic procedures [25].

In southern India, mango leaf is wide used for cleansing teeth. Sumant et al. [26-28] evaluated the effectivity of mango leaf as associate oral hygiene aid and obtained attention-grabbing findings. Higher soft deposit scores were according in cluster that used mango leaf. decay expertise during this cluster mistreatment mango leaf was like the cluster that used tooth brush. Mangiferin a compound gift in mango leaves had important medicinal drug property against bound strains of Pneumococci, Streptococci, Staphylococci, and eubacteria acidophilus.

The miswak (miswaak, siwak, sewak) could be a teeth cleansing twig made of made of a twig of the Salvadora persica tree, conjointly referred to as the hard liquor tree or the peelu tree and options in monotheism hygiene jurisprudence. The miswak is predominant in Muslim areas however its use predates the origin of Islam. In a study to assess antimicrobial activity of miswak chew stick in vivo, particularly on eubacterium mutans and lactobacilli complete that miswak had an instantaneous antimicrobial impact compared to toothbrush. Eubacterium mutans were a lot of prone to miswak than lactobacilli $[29,30]$.
In another study to look at relationship between chew sticks (Miswak) and animal tissue recession complete that miswak users had considerably a lot of sites with animal tissue recession than did toothbrush users [31]. Severity of recession was considerably a lot of pronounced in miswak users than in toothbrush users. In a scientific study in scrutiny the utilization of miswak with normal toothbrushes complete that the results clearly were in favor of the users UN agency had been mistreatment the miswak, provided they'd been given correct instruction in a way to brush mistreatment it [32].

Jivha Lekhana (Tongue scrapping): it's ideal to use gold, silver, copper, chrome steel for the scrapping of the tongue. Tongue scrapping stimulates the reflex points of the tongue. Removes dangerous odor (halitosis). Improves the sense of style, stimulate the secretion of organic process enzymes removes legion microorganism growth (approximately five hundred varieties). Clinical proof conjointly shows that use of tongue scrapers on an everyday basis, includes a vital Improvement on eliminating anaerobic microorganism and reduces dangerous odor [33].

Gandusha (Gargling) or Oil actuation: Oil pulling is associate degree ancient written material procedure that involves noisy oil within the mouth for oral and general health advantages. it's mentioned within the Avurvedic text Charaka Veda wherever it's known as Kavala or Gandusha and is claimed to cure concerning thirty general diseases starting from headache, cephalalgia to polygenic disorder and respiratory illness [34]. Oil actuation has been used extensively as a standard Indian people remedy for several years to stop decay, oral malodour, hemorrhage gums, status of throat, cracked lips and for strengthening teeth, gums and therefore the jaw. Oil actuation medical care may be done exploitation oils like oil or oil $[35,36]$. Oil actuation medical care is incredibly effective against plaque iatrogenic periodontitis each within the clinical and microbiological assessment.

Brushing is contra indicated within the cases of mouth ulceration, fever, dyspepsia, those that have tendency to vomit, asthma, cough, thirst. Oil actuation may be accustomed clean the rima oris altogether these cases. Gandusha and Kavala Graha area unit 2 primary oral cleansing techniques; specialised medical care to treat similarly on stop oral diseases. .

A study was conducted in 2009 to judge the impact of oil actuation with oil on plaque-induced periodontitis, and to match its efficaciousness with antiseptic gargle. The oil actuation medical care showed a discount within the plaque index, modified animal tissue scores, and total colony count of aerobic microorganisms within the plaque of adolescents with plaque-induced periodontitis [37].

Oil actuation may be a powerful detoxifying Ayurvedic technique that has recently become very fashionable as a CAM remedy for several completely different health ailments. Exploitation this technique, surgery or medication may well be prevented for variety of chronic diseases [38]. The oil medical care is preventative similarly as curative. The exciting side of this healing technique is its simplicity, written material advises oil gargling to purify the whole system; because it holds that every section of the tongue is connected to completely different organ like to the kidneys, lungs, liver, heart, tiny intestines, stomach, colon, and spine.

\section{Tissue Regeneration Therapies}

In written material, a herb, Amla (Phyllanthus emblica) known as the fruit of a tree, is taken into account a general rebuilder of oral 
health. Amla works well as a mouth rinse as a stewing. One to 2 grams per day may be taken orally in capsules for the semipermanent profit to the teeth and gums. Amla supports the healing and development of animal tissue once taken internally and conjointly profit the gums. Regular use of Bilberry and shrub berry fruits stabilize albuminoid and strengthens the gum tissue. Liquorice root promotes anti-cavity action, reduces plaque associate degreed has an anti-bacterial impact. Herbs like Rumex obtusifolius root, alfalfa leaf, cinnamon bark and turmericroot area unit taken internally to strengthen Astidharu, as an example, the skeleton and therefore the joints, have tried to be sensible for long run health of teeth. Outstanding examples embody Rumex obtusifolius root, alfalfa leaf, cinnamon bark, and herbaceous plant.

\section{Ayurvedic herbs with numerous oral health connected properties}

Ayurvedic medications have stood the take a look at of your time and since yesteryear been used for numerous ailments. Use of assorted Ayurvedic medication for oral and dental health. Numerous plants and natural product are used for his or her pharmacologic applications viz. antiulcer sequence, wound healing, anti-inflammatory drug, antimicrobial, inhibitor properties etc.

\section{Conclusions}

During this review an effort has been created to review varied seasoning plants mentioned in written material which will be used as associate adjunct for the upkeep of oral health. The literature showed that there are various Ayurvedic medication, which may be utilized in interference still as management of oral diseases. Several Ayurvedic seasoning plants, that are reviewed, possess antimicrobial, medication, analgesic, antiulcer sequence activities once screened in line with the trendy parameters. However, among them terribly negligible quantity of herbals extracts are utilized in clinical apply and therefore the remainder of others don't seem to be practiced thanks to their unknown pharmacological medicine effects. The clinical studies ought to be inspired to assess the efficaciousness still as toxicity of seasoning medication.

The normal data of written material ought to be integrated with the trendy medical specialty. For this, the active principles of plants ought to be incorporated into trendy oral health-care practices and dentists ought to be inspired to use natural remedies in varied oral health treatments. This may build medical specialty abundant safer, reasonable and additional accessible for the lower socio-economic teams in society.

\section{References}

1. Singh A, Purohit B (2011) Tooth brushing, oil pulling and tissue regeneration: A review of holistic approaches to oral health. J Ayurveda Integr Med 2: 64.

2. Shapiro H (2006) Medicine across cultures: history and practice of medicine in non-western cultures. Springer Science \& Business Media.

3. Dwivedi G, Dwivedi S (2007) Sushruta-the clinician-teacher par excellence. Indian J Chest Dis Allied Sci 49: 243-244.

4. Petersen PE, Bourgeois D, Ogawa H, Estupinan-Day S, Ndiaye C (2005) The global burden of oral diseases and risks to oral health. Bull World Health Organ 83: 661-669.

5. Petersen PE (2003) The World Oral Health Report 2003: continuous improvement of oral health in the 21 st century-the approach of the WHO Global Oral Health Programme. Community Dent Oral Epidemiol Dec 31: 3-24.
6. Jenkinson HF, Lamont RJ (2005) Oral microbial communities in sickness and in health. Trends Microbiol 13: 589-595.

7. Palombo EA (2011) Traditional medicinal plant extracts and natural products with activity against oral bacteria: potential application in the prevention and treatment of oral diseases. Evidence-Based Complementary and Alternative Medicine 2011.

8. Badria FA, Zidan OA (2004) Natural products for dental caries prevention. J Med Food 7: 381-384.

9. Park KM, You JS, Lee HY, Baek NI, Hwang JK (2003) Kuwanon G: An antibacterial agent from the root bark of Morus Alba against oral pathogens. J Ethnopharmacol 84: 181-185.

10. Chung JY, Choo JH, Lee MH, Hwang JK (2006) Anticariogenic activity of macelignan isolated from Myristica fragrans (nutmeg) against Streptococcus mutans. Phytomedicine 13: 261-266.

11. Prabu GR, Gnanamani A, Sadulla S (2006) Guaijaverin: A plant flavonoid as potential antiplaque agent against Streptococcus mutans. J Appl Microbiol 101: 487-495.

12. Hartzell JF, Zysk KG (1995) Health, science, and the spirit: Veda and Ayurveda in the Western world. J Altern Complement Med 1: 297-301.

13. Chatterjee A, Pakrashi S (1991) History of Indian medicine. The Treatise on Indian Medicinal Plants, (1st Edn) New Delhi: National Institute Science Communication and Information Resources, pp: 221-224.

14. Kosta S, Tiwari A (2009) A fusion of ancient medicinal plants with modern conventional therapies on its multifaceted anti diabetic properties. Pharmacol 1: 64-77.

15. Borchers AT (2004) Traditional Asian medicine and oral health. J Tradit Med 21:17-26.

16. Kelmanson JE, Jäger AK, van Staden J (2000) Zulu medicinal plants with antibacterial activity. J Ethnopharmacol 69: 241-246.

17. Goldstein BH. Unconventional dentistry: Part I. Introduction. J Can Dent Assoc 66: 323-326.

18. Balkrishna A (2006) Ayurveda: Its' philosophy and practice, Divya Prakashan: Haridwar, India.

19. Telles S, Naveen KV, Balkrishna A (2009) Use of Ayurveda in promoting dental health and preventing dental caries. Indian J Dent Res 20: 246.

20. Athavale VB (1999) Dant rogas. Dentistry in Ayurveda, (1st Edn), Chaukhamba Sanskrit Pratishthan: New Delhi, pp: 7-11.

21. Naik GH, Priyadarsini KI, Satav JG, Banavalikar MM, Sohoni DP,et al. (2003) Comparative antioxidant activity of individual herbal components used in Ayurvedic medicine. Phytochemistry 63: 97-104.

22. Venugopal T, Kulkarni VS, Nerurker RA, Damle SG, Patnekar PN (1998) Epidemiological study of dental caries. Indian J Pediatr 65: 883-889.

23. http://www.healthmantra.com/hctrust/art6.shtml.

24. Sumant G, Beena G, Bhongade L (1992) Oral Health status of young adults using indigenous oral hygiene methods. Stomatologica India 5: 17-23.

25. Almas K, Atassi F (2002) The effect of miswak and tooth brush filaments end-surface texture on enamel. Indian J Dent Res 13: 5-10.

26. Almas K, Al-Zeid Z (2004) To assess antimicrobial activity of miswak chewing stick (Salvadora persica) in vivo, especially on streptococcus mutans and lactobacilli. J Contemp Dent Pract 5:105-114.

27. Eid MA, Selim HA, Al-Shammery AR (1991) The relationship between chewing sticks (Miswak) and periodontal health. 2. Relationship to gingival recession. Quintessence Int 22: 61-64.

28. Al-Otaibi M, Al-Harthy M, Soder B, Gustafsson A, Angmar-Mansson B (2003) Comparative effect of chewing sticks and toothbrushing on plaque removal and gingival health. Oral Health Prev Dent 4: 301-307.

29. Kadam A, Prasad BS, Bagadia D, Hiremath VR (2011) Effect of Ayurvedic herbs on control of plaque and gingivitis: A randomized controlled trial. Ayu 32: 532-535.

30. Bethesda M (2006) A closer look at Ayurvedic medicine. Focus on complementary and alternative medicine. National Center for Complementary and Alternative Medicine (NCCAM), US National Institutes of Health (NIH) 12: 123-139. 
Citation: Neeraja Turagam, Durga Prasad Mudrakola (2017) The Scope of an Alternative Medicine to Cure Oral Diseases. Dentistry 7: 453. doi: $10.4172 / 2161-1122.1000453$

Page 4 of 4

31. Hebbar A, Keuskar V, Shetti A (2010) Oil pulling: Unraveling the path to mystic cure. J Int Oral Health 2: 11-14.

32. Asokan S (2008) Oil pulling therapy. Indian J Dent Res 19: 169.

33. Amith HV, Ankola AV, Nagesh L (2007) Effect of oil pulling on plaque and gingivitis. J Oral Health Community Dent 1: 12-18.

34. Asokan S, Emmadi P, Chamundeswari R (2009) Effect of oil pulling on plaque induced gingivitis: A randomized, controlled, triple-blind study. Indian J Dent Res 20: 47-51.

35. Singh A, Purohit B (2011) Tooth brushing, oil pulling and tissue regeneration: A review of holistic approaches to oral health. J Ayurveda Integr Med 2: 64-68.
36. Amruthesh S (2011) Dentistry and Ayurveda-V: An evidence based approach. Indian J Dent Res 2: 3-9.

37. Cowan MM (1999) Plant products as antimicrobial agents. Clin Microbiol Rev 12: 564-82.

38. Ahmad I, Beg AZ (2001) Antimicrobial and phytochemical studies on 45 Indian medicinal plants against multi-drug resistant human pathogens. J Ethnopharmacol 74: 113-23. 